\title{
Performance Analysis of Hybrid Renewable Power System with Simulation
}

\author{
Pranita Rathod ${ }^{1}$, Amit Chavhan ${ }^{2}$
}

\begin{abstract}
This project work depicts the performance analysis of a renewable energy based hybrid power system for improving power quality because optimal utilization of primary energy sources will increase the level of supply reliability. In this project we are going to design and simulate the power system containing more than two conventional energy forms i.e. solar, wind, diesel, fuel energy are combined together for the economic operation of energy generation. By using various graphs, we can analyse that the power output of new hybrid model is higher and more efficient than the power output of the wind/PV hybrid model. Due to variation in output power of solar panel, wind turbine and fuel cell, Diesel engine is also coupled to ensure reliable supply under all conditions. Regenerative cycle of fuel cell helps to dump excess energy from DC bus. The results show that the proposed hybrid power system can effectively manage the optimal utilization of primary energy sources and improves the power quality in an islanding as well as grid connected mode.
\end{abstract}

Keywords: hybrid power system, wind power system, solar power system, fuel cell system, diesel engine

\section{Introduction}

In hybrid power system there are various possibilities to make combination of different energy sources. Selection of energy source for hybrid system is mainly depends upon availability at the place where it going to stabilized. In general in India solar energy is available almost all the places and infrastructure for power generation is rugged. Hence need low maintenance so it is smart to choose to have $\mathrm{PV}$ one of the energy sources in hybrid system. According to increase demand of energy in world the science is developing the different energy generation systems, which can supply energy to the world under economic and environmental friendly conditions. Because, in society the energy is essential requirement to ensure the quality of life. Renewable energy has attracted the interests of researchers all around the world. The major challenge is to combine various existing sources in a single model so as to extract the usefulness of each of them while complementing each other's weaknesses. This dissertation proposes a method to integrate solar photovoltaic system, wind turbine system and diesel generator connected to a load. A dump load is also connected to the system to absorb the excess power. The hybrid system model has been developed in MATLAB/Simulink. The system is analysed in terms of the power generation and consumption. The results obtained are encouraging in terms of their stability. A hybrid system also called as standalone system supplies electricity to the load without being connected to the electric grid. Hybrid systems have applications in remote and inaccessible areas where the population is living without electricity.

This project depicts the performance analysis of a renewable energy based hybrid power system for improving power quality because optimal utilization of primary energy sources will increase the level of supply reliability. In this project the four conventional energy forms that is wind energy; photovoltaic cell; fuel cell and diesel generator are combine together for the economic operation of energy generation, In order to meet sustained load demands during varying natural conditions. Several stand-alone power systems installed around the world, usually located in small communities or at technical installations that are not connected to a main electricity grid. The majority of these power systems are based on fossil fuel power generation. Today there is $6.4 \%$ of the world's total use of renewable energy sources. So, there has been a growing initiative to include renewable energy technologies, particularly wind and/or solar power, into stand-alone power systems. When included in stand-alone power system, wind or solar power or both often operate in combination with diesel generators and batteries, reducing the fossil fuel consumption.

Replacement of batteries by fuel cells running on hydrogen, produced locally with renewable energy, offers a great opportunity to improve environmental standards, and reduce operation and maintenance costs. Unlike a storage battery, which also represents an attractive back-up option, such as fast response, modular construction and flexibility, the fuel cell power can produce electricity for unlimited time to support the PV power generator. Therefore, a continuous supply of high quality power generated from the PVFC hybrid system is possible day and night. Therefore, the fuel cell power system has a great potential for being coordinated with the PV generator to smooth out the photovoltaic power's fluctuations.

\section{Literature Survey}

This contains the literature review materials pertinent to this research.

1) Gow developed a general PV model which could be implemented on simulation platforms such as PSPICE. The model accepted irradiance and temperature as variable parameters and outputted the V-I characteristic for the particular cell used in the paper under certain conditions.[1]

2) Dihrab presented a hybrid solar-wind system as a renewable source of power generation for grid-connected application in three cities in Iraq. The proposed system was simulated using MATLAB, in which the input parameters for the software were the meteorological data for the selected locations and the sizes of PV and wind turbines. Dihrab's results showed that it is possible for Iraq to use the solar and wind energy to generate enough power for some villages in the desert or rural area. [2]

3) Reichling modelled a hybrid solar-wind power plant in south western Minnesota for a two year period, using 


\section{International Journal of Science and Research (IJSR) \\ ISSN (Online): 2319-7064}

Index Copernicus Value (2015): 78.96 | Impact Factor (2015): 6.391

hourly solar irradiation and wind speed data. Reichling compared the market value of energy produced, retail value of energy produced, and the levelized cost of energy of the hybrid plant to those of an energy equivalent wind-only plant. The results showed that adding solar thermal electric generating capacity to a wind farm rather than expanding with additional wind capacity provides cost-benefit trade-offs. [3]

4) Ekren, showed an optimum sizing procedure of wind-PV hybrid system in Turkey. Several modelling studies on PV-wind turbine power system have been conducted. [4]

5) Among them, Kim developed a grid-connected photovoltaic model using PSCAD for electromagnetic transient analysis where a simple circuit model of the solar array was used to easily simulate its inherent characteristics with the basic specification data.[5]

This project work analyze the performance of the system which presents an economic evaluation of a hybrid wind/solar/fuel cell/diesel engine generation system and a cost comparison with a wind/solar system more over a computer program has been developed to the system components in order to match the load of the site in most effective way. The study way performed using graphic user interface programmed in matlab. In this project simulation of the hybrid system under investigation was carried out by using matlab/ simulink software. This project analyze the system which presents a fuel cell simulator designed and manufactured as electrical characteristic of fuel cell generation system using a simple buck converter to overcome the high price of the fuel cell system.

\section{Methodology}

Hybrid Power System:-Integration of two or more renewable energy source (in this case) form a more reliable system is called a hybrid system. Renewable energy systems (RESs) are one of the most suitable and environmentally friendly solutions to provide electricity within urban and rural areas. On-grid and off-grid electrification based on the generation of power through the installation of renewable energy power systems in urban and rural households have been proven to be capable of delivering high quality and reliable electricity for heating, lighting, and demands alike.
Selection of hybrid system options: As it can be noticed from the Object structure of a hybrid energy system, there are a great number of potential hybrid system options with different energy system elements. In the demonstration of the potential options to be taken in this analysis, we have selected the following options:

1) Solar PV PP, wind turbine power plant (WTPP), biomass thermal steam turbine power plant

(BTLSTPP) for production of electricity and hydrogen

2) Diesel and Wind PP for production of electricity and hydrogen

3) BTLSTPP and WPP for production of electricity and hydrogen

4) Combined cycle gas turbine power plant for electricity and

5) Hydrogen production

6) Cogeneration of electricity and water by the hybrid system.

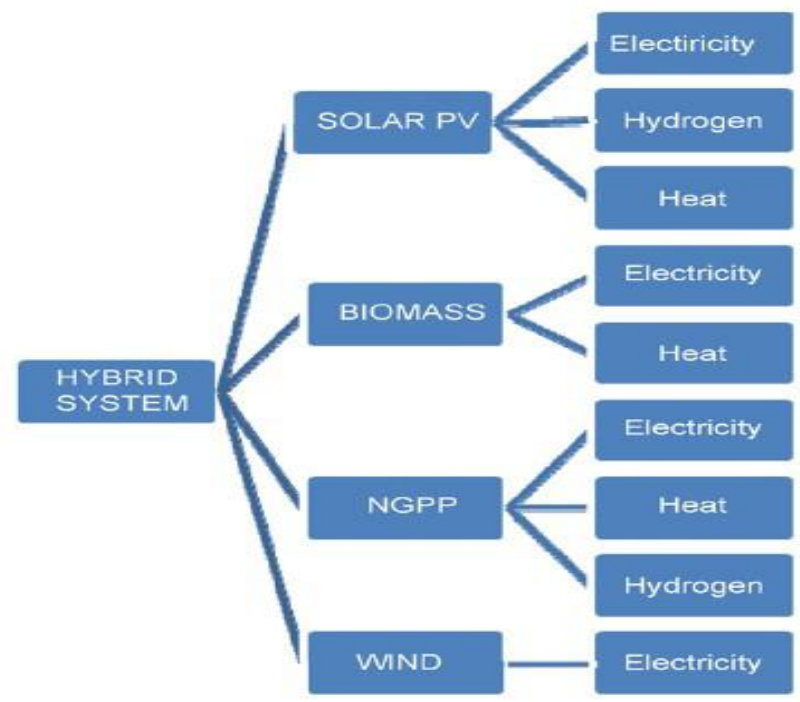

Figure: Hybrid energy system structure

\section{System Model Description}

\section{> Model of Proposed Hybrid System:-}

The simulated model of our proposed hybrid system is designed as follows:-
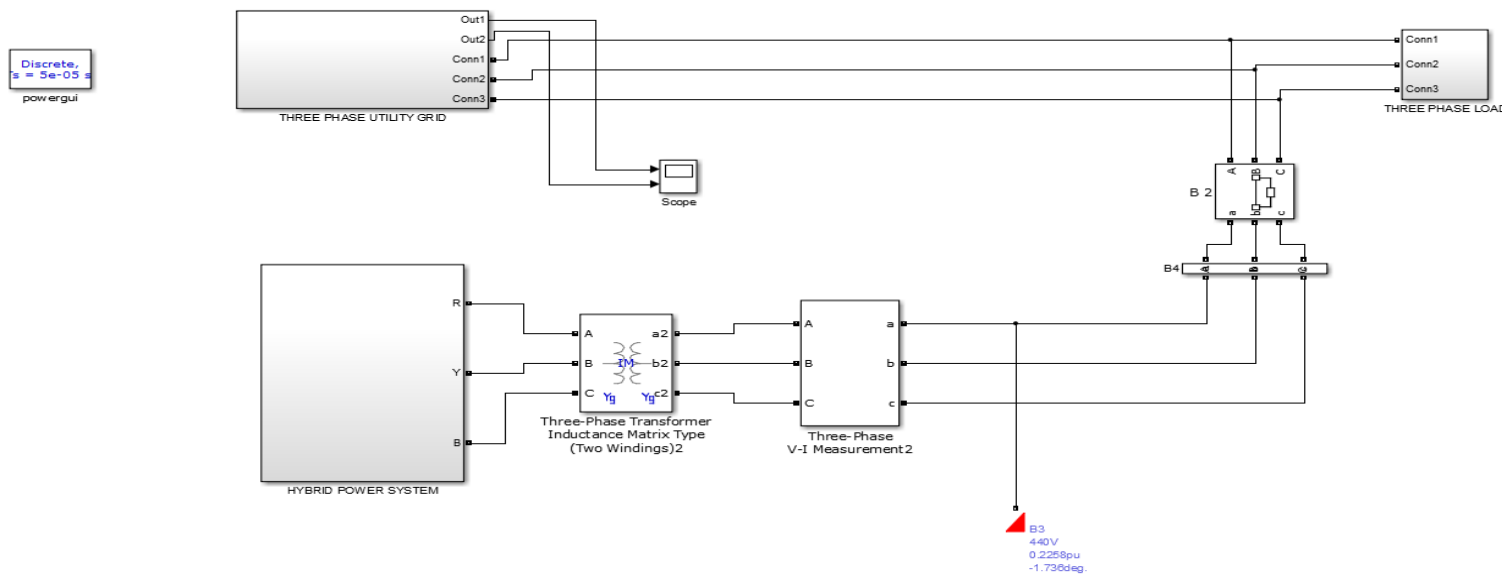

Figure: Simulated model of wind/solar/fuel cell and diesel generator 


\section{International Journal of Science and Research (IJSR) \\ ISSN (Online): 2319-7064 \\ Index Copernicus Value (2015): 78.96 | Impact Factor (2015): 6.391}

Our proposed system involves the combination of four energy sources which includes wind turbines, solar energy, fuel cell, diesel generator system. The supply of generated power feeds to the three phase utility grid via three phase transformer (inductance matrix type) and three phase breaker. The three phase load is also provided to the utility grid.

In many regions of the world, the fluctuating nature of solar radiation means that purely $\mathrm{PV}$ power generators for off grid applications must be large and thus expensive. One method to overcome this problem is to integrate the photovoltaic plant with other power sources such as diesel, fuel cell (FC), or battery backup. The newly invented hybrid system containing wind power system, solar system, fuel cell and diesel generator. We are going to analyze the performance of the hybrid system and comparing the result of this hybrid system with the other hybrid systems which are already existing. After discussing all the power sources which are used in this hybrid system in detail, we turn towards the result of the hybrid system.

The model for the hybrid system is designed as follows:-

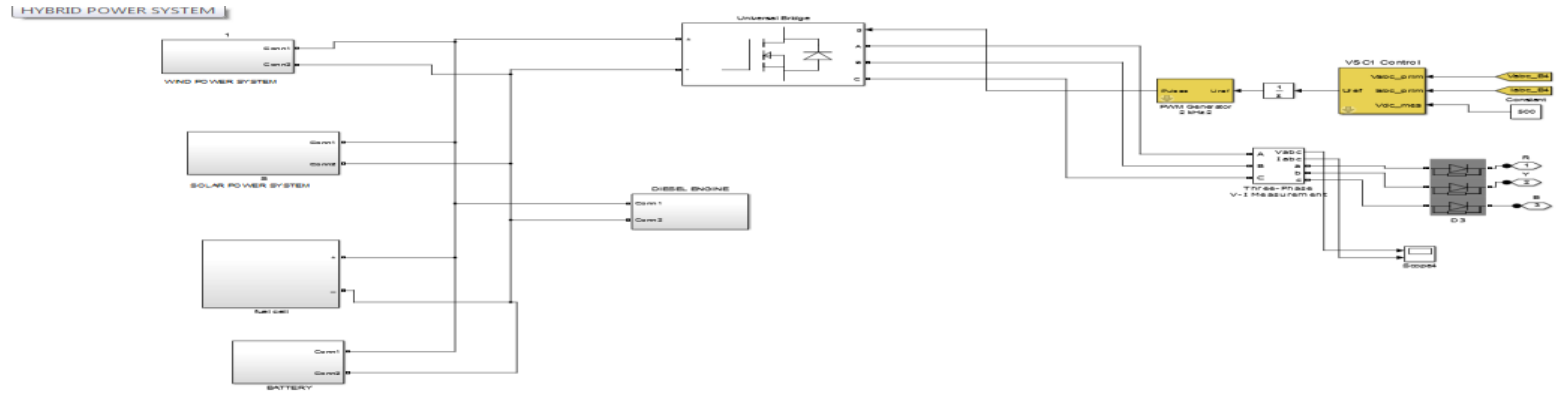

Figure: Model of hybrid power system

Usually one of the energy sources is a conventional one which necessarily does not depend on renewable energy resource powered by a diesel engine, while the other(s) would be renewable viz. solar photovoltaic, wind or hydro. The design and structure of a hybrid energy system obviously take into account the types of renewable energy sources available locally, and the consumption the system supports.

The proposed Hybrid power system contains the combination of following power systems as sources:-

1. Wind Power system

2. Solar system

3. Fuel cell

4. Diesel generator System

Modeling of the Components of Hybrid Power System is given as follows:-

\section{$>$ Wind Power System:-}

The wind generator set consists of a wind turbine, synchronous generator, rectifier, and inverter to get an ac supply. Basically the wind turbine sends the wind's kinetic energy in the rotor which is mechanically coupled to generators.Wind energy source is also a good choice but more preferable for open land hybrid system and status of wind throughout the year is also important. India has monsoon climate hence has enough potential of wind energy. Wind turbine is a device that converts kinetic energy from the wind into electrical power.
A wind turbine used for charging batteries may be referred to as a wind charger.

The Simulink model for wind turbine is shown in Fig below

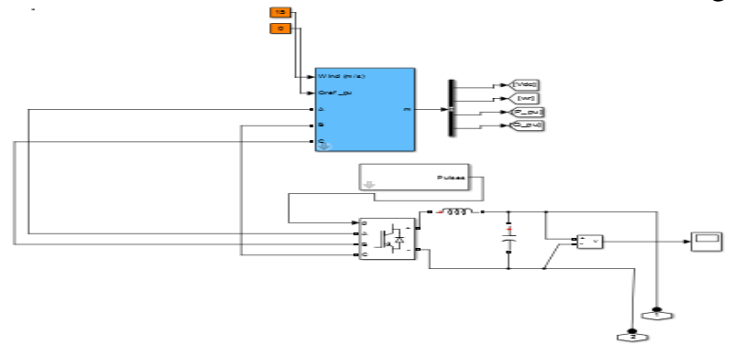

Figure: Simulated model of wind power system

\section{$>$ Solar Power System}

Insolation (short for incident or incoming solar radiation) is a measure of solar radiation energy received on a given surface area and recorded during a given time. It is also called solar irradiation and expressed as "hourly irradiation" if recorded during an hour or "daily irradiation" if recorded during a day. The unit recommended by the World Meteorological Organization is mega joules per square metre $(\mathrm{MJ} / \mathrm{m} 2)$ or joules per square millimeter $(\mathrm{J} / \mathrm{mm} 2)$. An alternate unit of measure is the Langley (1 thermo chemical calorie per square centimeter or 41,840 $\mathrm{J} / \mathrm{m} 2)$. 


\section{International Journal of Science and Research (IJSR) \\ ISSN (Online): 2319-7064}

Index Copernicus Value (2015): 78.96 | Impact Factor (2015): 6.391

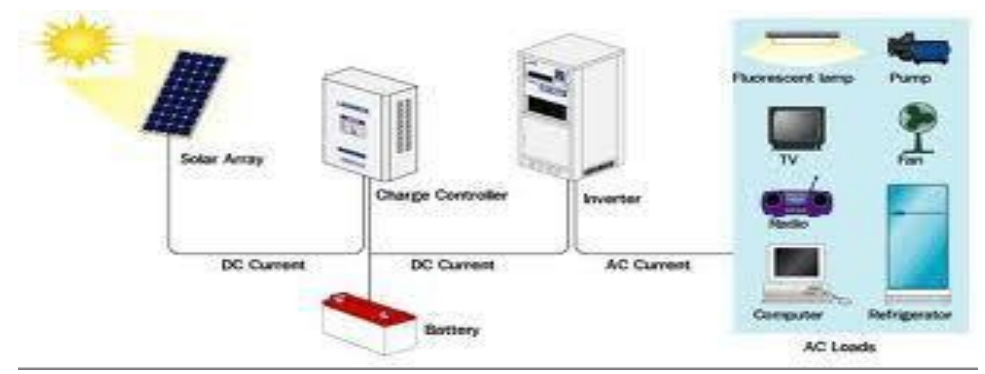

Figure: An Illustration of standalone solar system

Practitioners in the business of solar energy may use the unit watt-hours per square metre $(\mathrm{Wh} / \mathrm{m} 2)$. If this energy is divided by the recording time in hours, it is then a density of power called irradiance, expressed in watts per square metre $(\mathrm{W} / \mathrm{m} 2)$. Solar electric systems sometimes produce more electricity than your home needs. This extra electricity is either stored in batteries or fed into the utility grid. Homeowners can be given credit by their local power companies for the electricity produced at their homes through "net metering" programs. A photovoltaic energy system is mainly powered by solar energy. The configuration of PV system is manifested in figure. The model of solar power system is simulated as follows:-

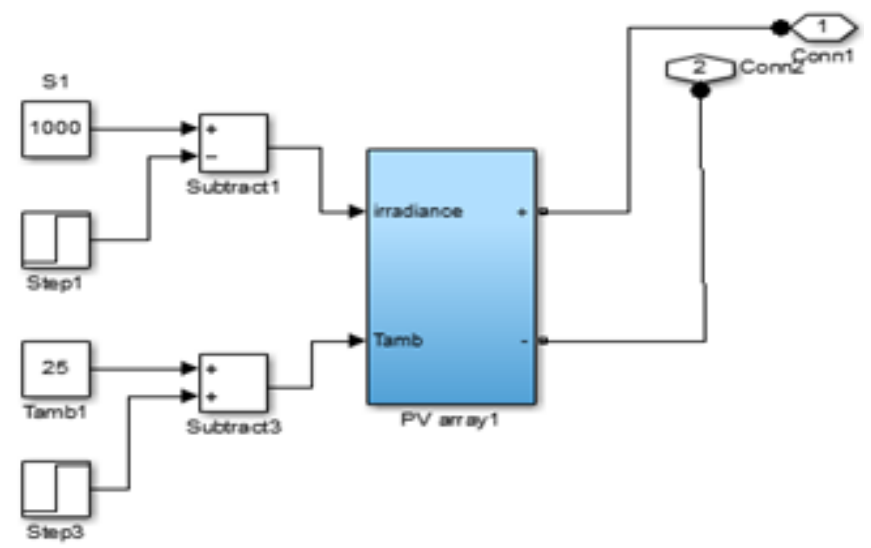

Figure: Model of solar power system

It contains PV modules or arrays, which convert solar energy in the form of solar irradiation into electric energy. The dc-dc converter changes the level of the voltage to match it with the electrical appliances that are supplied by this system. This DC-DC converter may be either buck or boost or buck-boost contingent on the required and available voltage levels. The maximum power point tracing system coerces the maximum power from the PV modules. A bidirectional converter which is able to supply the current in both the directions is used to charge the battery when there is a power surplus and the energy stored by the battery is discharged into the load when there is a power deficit.

\section{$>$ Fuel Cell System}

A fuel cell is a device that uses hydrogen as a fuel to produce electrons, protons, heat and water. Fuel cells are electrochemical devices that convert the chemical energy of a reaction directly into electrical energy. The fuel cell must provide competitive, reliable, and quality power without emitting pollutants such as oxides of nitrogen, carbon or sulphur. It must respond quickly to changes in load and have low maintenance requirements as well as a long cell life. In the schematic of fuel cell, gaseous fuels are fed continuously to the anode, and an oxidant i.e., oxygen from air, is fed continuously to the cathode compartment, the electrochemical reactions take place at the electrodes to produce an electric current. A fuel cell is individual small unit of around $1.2 \mathrm{~V}$. A group of units are connected in series and in parallel to get required voltage and current ratings, that group is called fuel cell stack. Current fuel cells, when operated alone have efficiencies of about 40-55\%. Fuel cell technology is based upon the simple combustion reaction (1)

$$
2 \mathrm{H} 2+\mathrm{O} 2 \leftrightarrow 2 \mathrm{H} 2 \mathrm{O}
$$

The modelling of fuel cell system is shown as follows

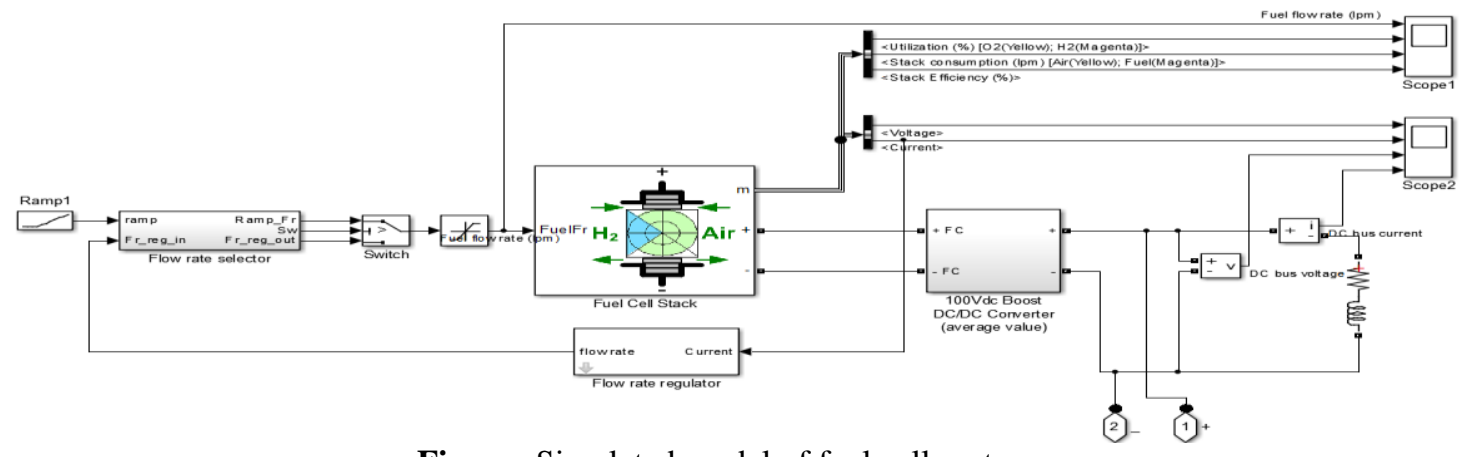

Figure: Simulated model of fuel cell system

\section{> Diesel Generator System:-}

A diesel generator is the combination of a diesel engine with an electric generator (often an alternator) to generate electrical energy. This is a specific case of engine-generator. Diesel generating sets are used in places without connection to the power grid, as emergency power-supply if the grid fails, as well as for more complex applications such as peaklopping, grid support and export to the power grid. Sizing of diesel generators is critical to avoid low-load or a shortage 


\section{International Journal of Science and Research (IJSR) \\ ISSN (Online): 2319-7064 \\ Index Copernicus Value (2015): 78.96 | Impact Factor (2015): 6.391}

of power and is complicated by modern electronics, specifically non-linear loads.

To attenuate shortfalls in energy production during periods of poor sunshine, photovoltaic systems require a backup diesel generator for increased system availability and minimum storage requirements. The choice of diesel generator depends on type and nature of the load. A battery bank is the result of joining two or more batteries together for a single application. By connecting batteries in series, parallel \& series and parallel, you can increase the voltage or amperage, or both.

The simulated model of the diesel generator is designed as follows

\section{Engine}

Generator

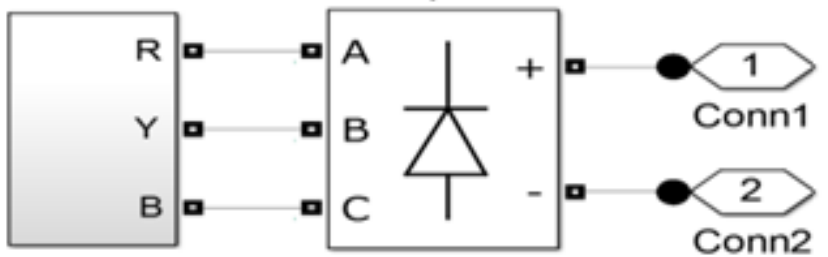

Figure: Simulated model of diesel generator

In this model the synchronous generator is used for the generating purpose. The engine generator gives two outputs connecting to the ad/dc convertor. The diesel engine generator is form by combining mechanical engine turbine and the generator control unit (GCU) shown in fig.5.14.The Mechanical engine is used to control speed and it gives it to the synchronous generator and the field voltage is provided to the generator by GCU shown in fig.below

Model of generator is shown in fig

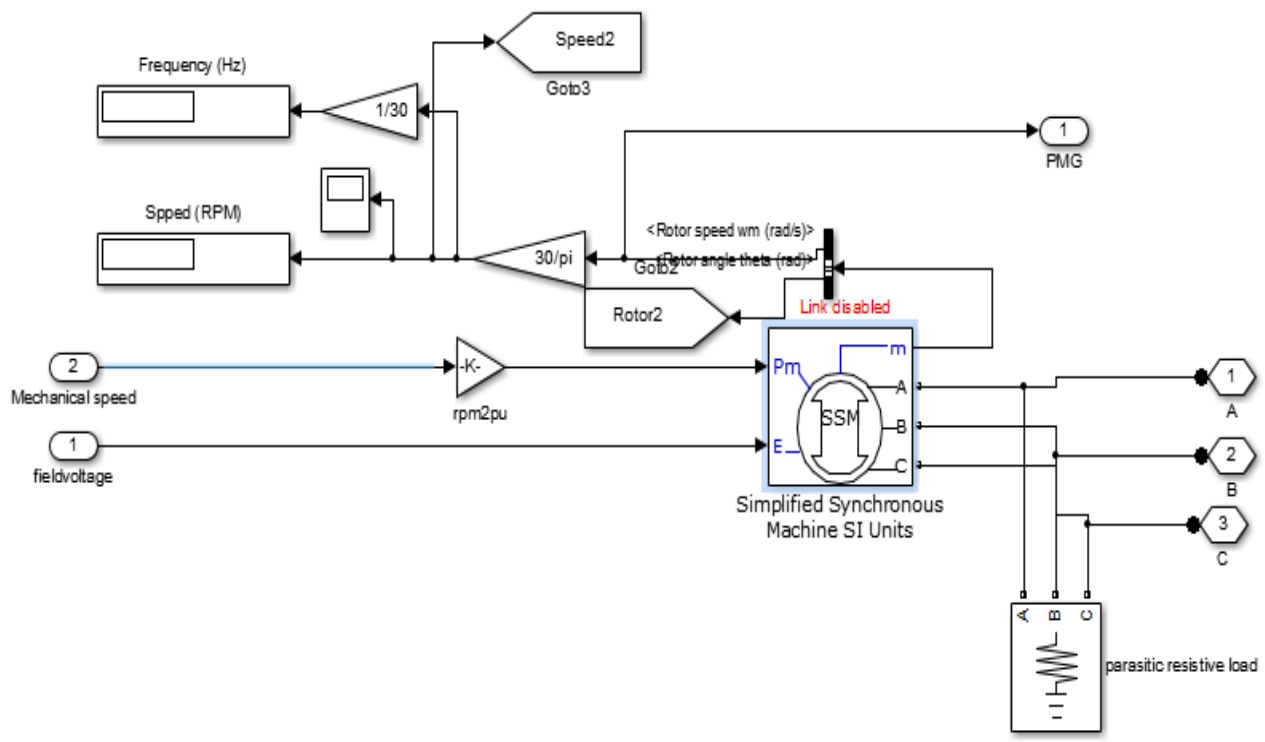

Model of Generator

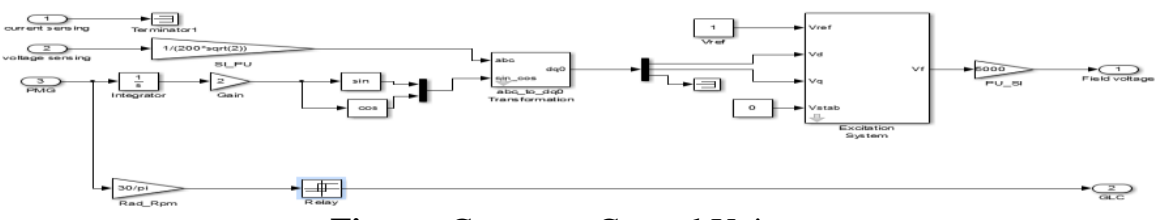

Figure: Generator Control Unit

\section{Experimental Result and Analysis \\ $>$ Output of Wind Power System}

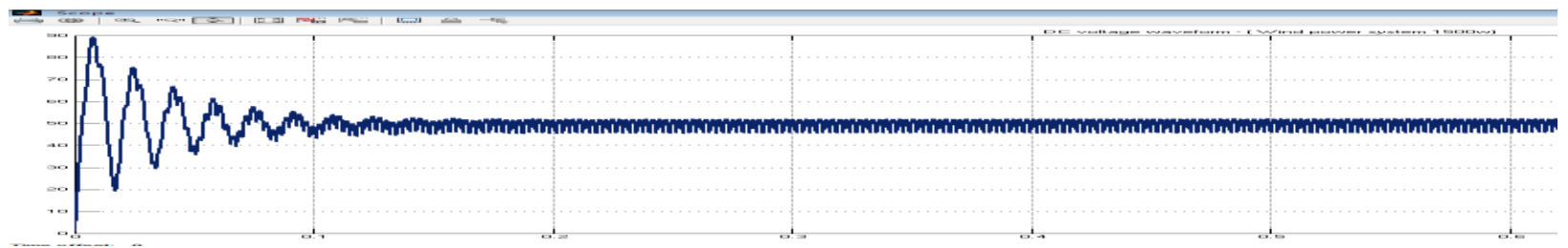

Figure: DC voltage waveform for wind energy

The wind turbine generator, the solar photovoltaic system and the diesel generator produces power in such a way that the generated power is equal to the power consumed. During the sudden increase or decrease in the load the diesel generator acts as a backup supply and supplies the deficit power. The waveforms of the powers generated and supplied are shown in fig 


\section{International Journal of Science and Research (IJSR) \\ ISSN (Online): 2319-7064 \\ Index Copernicus Value (2015): 78.96 | Impact Factor (2015): 6.391}

The fig shows that the dc voltage is become constant from the time $0.1 \mathrm{sec}$ accelerating in between $40-50 \mathrm{~V}$. Here the

wind power system is $1500 \mathrm{~W}$.

\section{Result of scope 1 of fuel cell.}

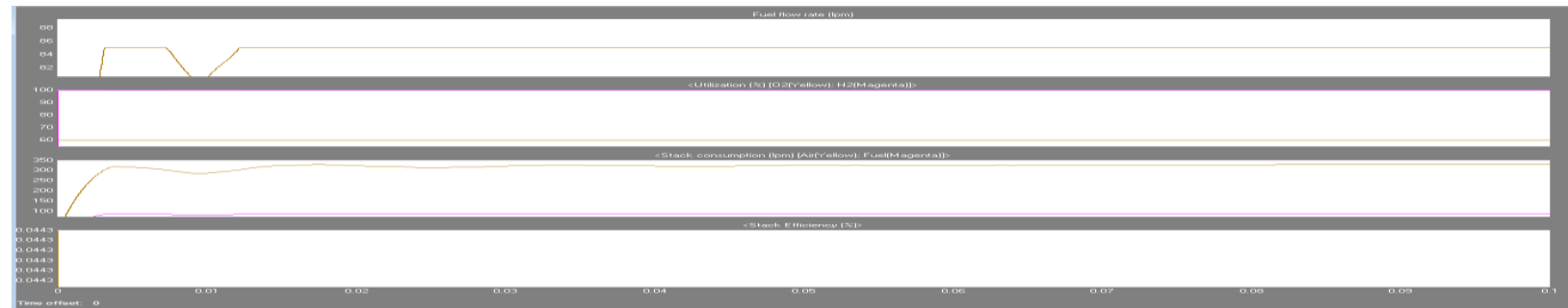

Figure: Output of fuel flow rate, utilization, stack consumption \& stack efficiency

Result of scope 2 of fuel cell.

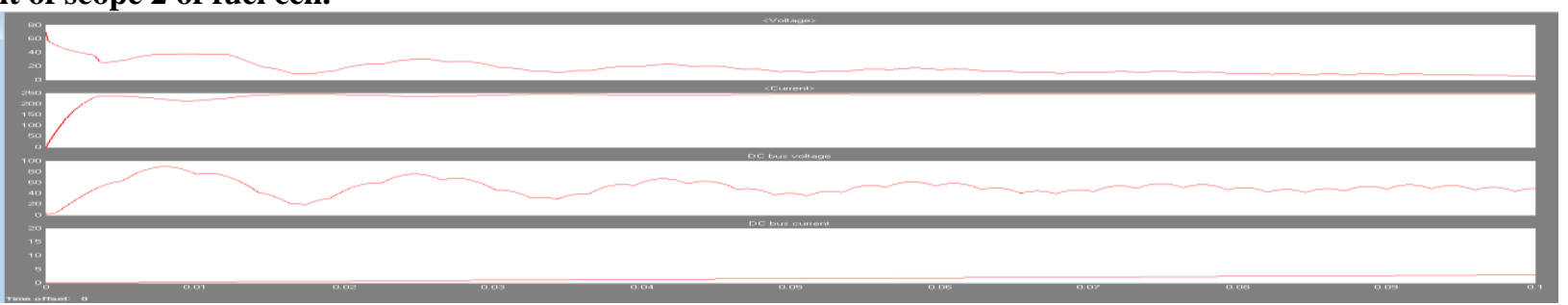

Figure: Output of current, voltage, dc bus current, dc bus voltage

\section{$>$ Performance of the Wind, Solar Hybrid Systems}

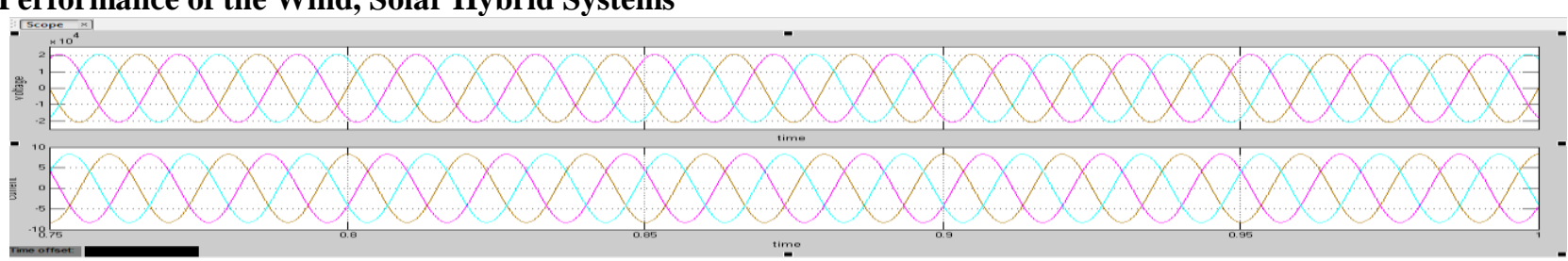

Performance of Wind, Solar And Fuel Cell Hybrid Power System

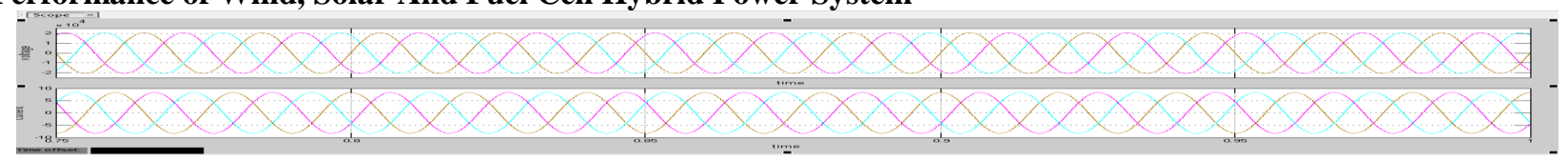

The graphical representation of the wind/pv/fuel cell/diesel generator hybrid system.I

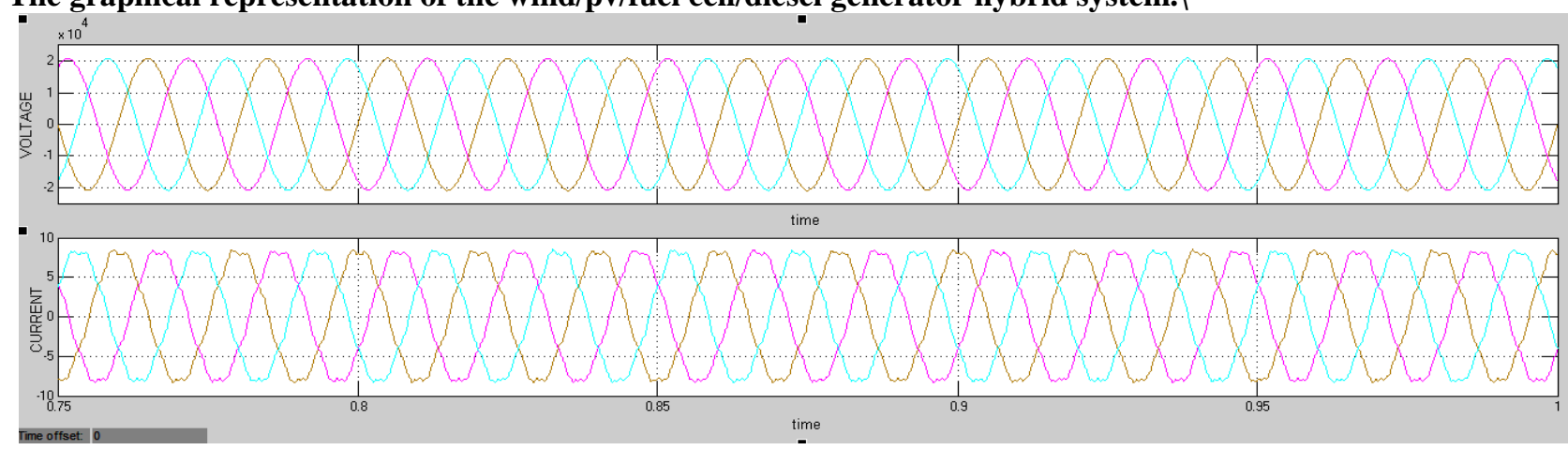

From the above output graph of performance of different hybrid systems, it is prove that the performance of wind/solar and fuel cell hybrid system gives better efficiency than other system but the continuity of power supply is done by using diesel generator in that hybrid system.

Though there is fluctuation in the output of hybrid system involving wind/solar/fuel cell and diesel generator system but the diesel generator is used for the backup storage so the supply of power will be continuous so this hybrid system is better than the other existing hybrid systems.

\section{Conclusion}

The hybrid energy systems are recognized as a viable alternative to grid supply or conventional, fuel-based, remote area power supplies all over the world. The literature review reveals that, renewable energy based low emission hybrid systems are not cost competitive against conventional

\section{Volume 6 Issue 7, July 2017} www.ijsr.net 


\section{International Journal of Science and Research (IJSR) \\ ISSN (Online): 2319-7064}

Index Copernicus Value (2015): 78.96 | Impact Factor (2015): 6.391

fossil fuel power systems. However, the need for cleaner power and improvements in alternative energy technologies bear good potential for widespread use of such systems. Moreover, the rural households in industrialized and less developed countries attach high value to a reliable, limited supply of electricity. Community facilities such as rural hospitals, schools, telecommunication and water pumping stations can contribute significantly to the welfare of people and rural development.

In this paper, a renewable energy based hybrid power system, its energy management and control system is proposed. It is modeled for an isolated load/grid connected load using static converters. Diesel engine is also coupled to ensure the reliable supply under all conditions. This proposed system facilitates improvement in power quality which ensures continuous and reliable supply to loads. Therefore, this system can tolerate the rapid changes in load and environmental conditions and suppress the effects of these fluctuations and provides optimum utilization of available resources.

\section{Future Scope}

- In this hybrid system with using fuel cell is more efficient, long life and cheapest.

- The use of solar/wind/fuel cell \& diesel generator hybrid power generation is an especially, vivid and relevant choice for as these are power sources of technological, political, and economic importance in their state. In other places, other power sources could be used.

- The hybrid combinations of wind power, solar power, geothermal power, hydroelectric power, tidal power, biomass generated power, power from incineration of solid wastes, and many other technologies could be considered depending on local interests and resources.

- Moreover, the less-fortunate rural households in less developed countries attach high value to a reliable, limited supply of electricity.

- Although the cost reduction and technological development of hybrid energy systems in recent years has been encouraging, they still remain an expensive source of power.

- To allow the widespread application of this emerging technology, there is a need for further R\&D improvements in $\mathrm{PV} /$ wind/FC/DE technologies that can reduce the cost of hybrid systems.

- The cost of conventional energy resources is increasing every year, but the receding trend in the cost of renewable energy technologies because of its widespread use is an encouraging factor, projecting renewable energy systems an economical means of power generation in future for many hybrid and standalone applications.

- Finally, it is extremely important to focus on designing the most optimal hybrid controllers in a way to manage the power flow between the systems components such that energy cost is minimum and load requirements could be met round the year.

\section{References}

[1] Gow, J. A., and C. D. Manning, "Development of a photovoltaic array model for use in power-electronics simulation studies," in IEEE Proceedings- Electric Power Applications, vol.146, pp. 193-199, Mar. 1999.

[2] Dihrab, S., and K. Sopian, "Electricity generation of hybrid PV/wind systems in Iraq," in Renewable Energy, vol. 35, pp. 1303-1307, Jun. 2010.

[3] Reichling, J. P., and F.A. Kulacki, "Utility scale hybrid wind-solar thermal electrical generation: a case study for Minnesota," in Energy, vol. 33, pp. 626-638, Apr. 2008.

[4] Ekren O., B. Y. Ekren, and B. Ozerdem, "Break-even analysis and size optimization of a PV/wind hybrid energy conversion system with battery storage - A case study," in Applied Energy, vol. 86, pp. 1043-1054, Jul.Aug. 2009.

[5] Kim, S. K., J. H. Jeon, C. H. Cho, and E. S. Kim, "Modeling and simulation of a gridconnected PV generation system for electromagnetic transient analysis," in Solar Energy, vol.83, pp. 664-678, May 2009.

[6] Tsai, H. L., "Insolation-oriented model of photovoltaic module using Matlab/Simulink," in Solar Energy, vol. 84, pp. 1318-1326, July 2010.

[7] Yang, H., Z. Wei, and L. Chengzh, "Optimal design and technoconomic analysis of a hybrid solar-wind power generation system," in Applied Energy, vol. 86, pp. 163-169, Feb. 2009.

[8] Khan, M. J., and M. T. Iqbal, "Dynamic modeling and simulation of a small wind fuel cell hybrid energy system," in Renewable Energy, vol. 30, pp. 421-439, Mar. 2005.

[9] Hossain, M. Zakir, A. K. M. Sadrul Islam, and D.G. Infield, "PV-Wind Hybrid System Modelling for Remote Rural Application," in Journal of The Institution of Engineers, vol. 32, pp. 37-44, Dec. 2007.

[10] Chang, J., and Shu-Yun Jia, "Modelling and application of wind-solar energy hybrid power generation system based on multi-agent technology," in IEEE International Conference on machines learning and cybernetics, vol. 32, pp. 1754-1758, Jul. 2009.

[11] Castle, John A., James M. Kallis, Sally M. Moite, and Neil A. Marshall, "Analysis of Merits of Hybrid Wind/Photovoltaic Concept for Stand-Alone Systems," in 15th IEEE Photovoltaic Specialists Conference, vol. 738-744, May 1981.

[12] IEA (2011), "Energy for All: Financing access for the poor," OECD/IEA, Oslo.

[13] ARE - shining a Light for a progress, "Hybrid power systems based on renewable energies- A suitable and cost-competitive solution for rural electrification," available

at: www.ruralelec.org/fileadmin/DATA/Documents/06_Pu blications/Position_papers/AREWG_

Technological_Solutions_-

_Brochure_Hybrid_Systems.pdf, Ed.: ARE-Alliance for Rural Electrification, 2008. 


\section{Author Profile}

Pranita V. Rathod is Assistant professor (Electrical Engineering Department), Babasaheb Naik College of Engineering, Pusad.

Amit D. Chavhan is Assistant professor (Computer Science Engg. Department), Babasaheb Naik College of Engineering, Pusad. 